\title{
Insecticide resistance of adult housefly in Hokkaido ${ }^{1)}$
}

\author{
By \\ Akifumi Hayashi $^{2 \gamma}$, Masayoshi Hatsukade ${ }^{2)}$, Megumi Hasegawa ${ }^{3)}$ \\ and Keisaku Hattori ${ }^{3)}$
}

(Received: August 18, 1971)

Though the development of resistance to insecticides has become one of the most important problems in relation to insect control in Japan, only a little reliable datum on resistance of medical insects in Hokkaido is available. In the case of the housefly, only a report was published by Yasutomi (1961 a) on the resistance levels of colonies collected at several spots in Hokkaido.

In 1970, houseflies were collected from various places in Hokkaido, and their resistance levels to insecticides were evaluated and compared with those of housefly colonies collected in Honshu.

\section{TEST Insects and METHODS}

Insects: Two or three couples of the housefly, Musca domestica vicina, were collected from garbage cans, garbage dumping places or pigpens at 44 places in Hokkaido, and brought to the tests after breeding for three or four generations in the laboratory.

Larvae were reared with the Oriental's Animal Food (Powder for the rearing of experimental animals, Oriental Yeast Manufactứring Co.).

Adults were fed with a $2 \%$ sucrose solution. Only female flies were brought to the tests on 3 to 4 days after the emergence.

Insecticides used: Eight kinds of insecticides; lindane $(\gamma$-BHC), malathion, dichlorvos (DDVP), diazinon, fenitrothion (Sumithion), bromophos, pyrethrins and allethrin, were used as test chemicals. These chemicals

1) A part of this work was already published in "Botyu-Kagaku" 36, 41 (1971).

2) 林 晃史 - 甘日出正美 : Laboratory of Applied Entomology, TAISHO Pharmaceutical Co., Ltd.

3）長谷川 恩 - 服部畦作 : Hokkaido Institute of Public Health. were dissolved in acetone and applied to the test insects.

Test method (Topical application) : Half $\mu \mathrm{l}$ of serial dilution of the insecticides was. applied topically onto dorsum of each fly using a microsyringe. Each dilution was. tested on 20 flies and the experiment was repeated three times. After the treatment flies were transferred to containers in a constant temperature chamber held at 24 to $27^{\circ} \mathrm{C}$, and fed with $2 \%$ sucrose solution. The mortality was counted at 24 hours after the treatment.

Evaluation of the level of resistance: The dosage required to produce $50 \%$ mortality (LD50) was used as the basis for comparison of resistance level. The LD50 of Takatsuki strain, which has never exposed to any insecticides, was used as the reference value.

\section{Results and Discussion}

Results of the tests in flies collected from Hokkaido and Honshu are summarized in Table 1 and 2 .

Comparison of the resistance to lindane: Though the considerable variation in LD50 value of Takatsuki strain to $\gamma$-BHC was reported by Nagasawa (1962), the LD50 value of $4.547 \mu \mathrm{g}$ per female fly was obtained in the present study. Many samples of flies in Hokkaido were less susceptible to $\gamma$-BHC than the Takatsuki strain. The highest resistance level for $\gamma$-BHC was observed in Otaru colony, with the LD50 value of 84.19 $\mu \mathrm{g}$.

Comparison of the resistance to malathion: All samples of flies collected in Hokkaido were higher resistant to malathion than the Takatsuki strain. LD50 values of Japanese houseflies for malathion reported by several 


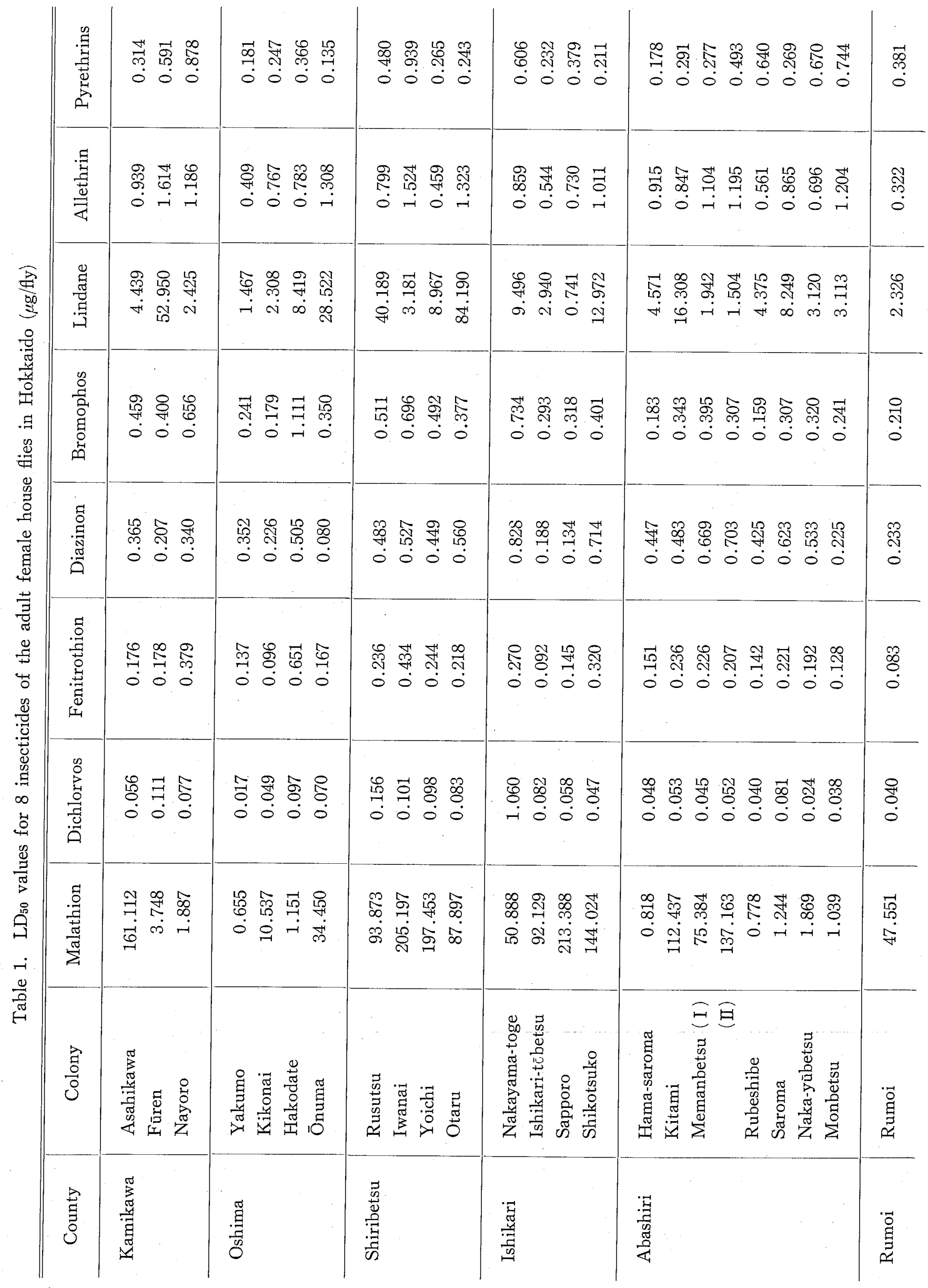




\begin{tabular}{|c|c|c|c|c|c|c|c|c|}
\hline 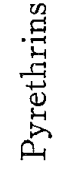 & 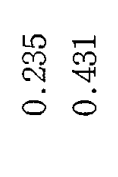 & 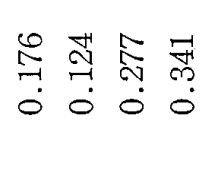 & 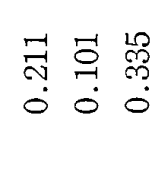 & 商 & 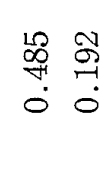 & 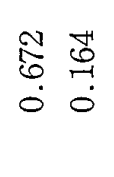 & 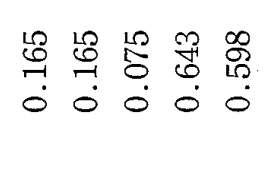 & 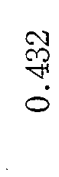 \\
\hline 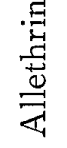 & 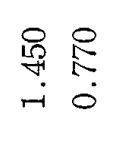 & 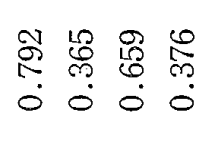 & 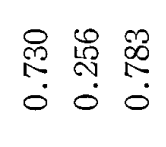 & $\stackrel{\mathscr{Z}}{\stackrel{2}{0}}$ & \begin{tabular}{ll} 
กิ & $\infty$ \\
ก⿱ & \multicolumn{2}{c}{} \\
0 & 0 \\
0 & 0
\end{tabular} & $\begin{array}{ll}0 & \infty \\
2 & 0 \\
1 & 0 \\
0 & 0\end{array}$ & 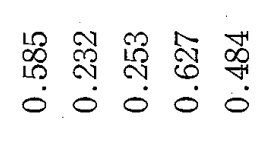 & : \\
\hline 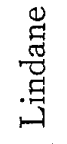 & $\begin{array}{ll}R & -1 \\
0 & 6 \\
0 & 0\end{array}$ & 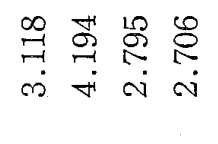 & 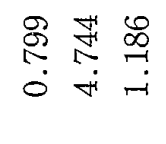 & $\begin{array}{l}\mathscr{m} \\
\stackrel{\leftrightarrow}{*} \\
\sim\end{array}$ & 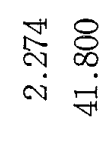 & 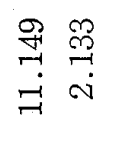 & 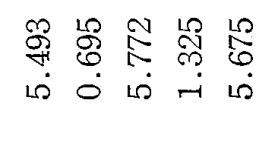 & $\begin{array}{l}\text { जै } \\
\text { गे }\end{array}$ \\
\hline 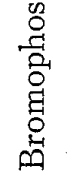 & \begin{tabular}{ll}
$\infty$ & $R$ \\
$\infty$ & $R$ \\
$\infty$ & \multirow{H}{*}{} \\
0 & 0
\end{tabular} & 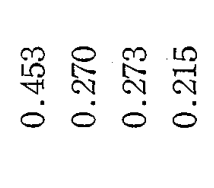 & 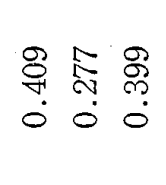 & $\stackrel{m}{\vec{N}}$ & 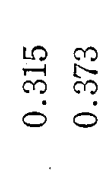 & 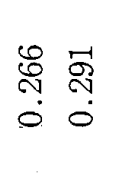 & 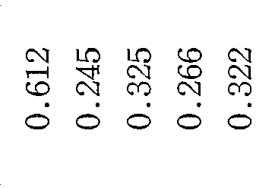 & $\stackrel{\vec{N}}{\stackrel{0}{\circ}}$ \\
\hline 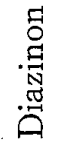 & 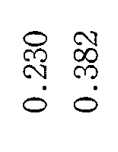 & \begin{tabular}{llll}
$\infty$ & 9 & $\overrightarrow{1}$ & 0 \\
0 & \multirow{5}{*}{} & 10 & $m$ \\
0 & 0 & 0 & 0
\end{tabular} & $\begin{array}{lll}\infty & 1 & 9 \\
8 & 1 & 0 \\
0 & 0 & 0 \\
0 & 0\end{array}$ & ڤ్ల & \begin{tabular}{ll}
10 & \multirow{1}{*}{} \\
$\infty$ & \multirow{4}{*}{} \\
0 & 0
\end{tabular} & 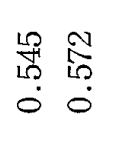 & 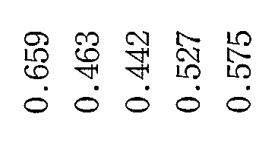 & $\begin{array}{l}\infty \\
\stackrel{0}{*} \\
\vdots \\
0\end{array}$ \\
\hline 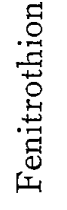 & 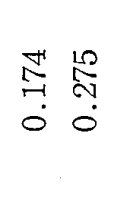 & 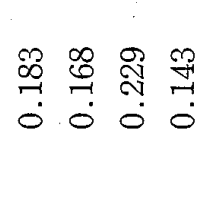 & 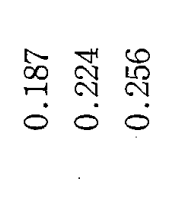 & $\begin{array}{l}180 \\
? \\
0 \\
0\end{array}$ & $\begin{array}{l}\hat{M} \\
\stackrel{N}{0} \\
\stackrel{0}{0} \\
0\end{array}$ & $\begin{array}{l}\text { ज. } \\
\text { A. } \\
\vdots \\
0\end{array}$ & 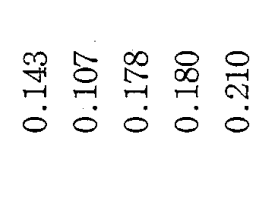 & \begin{tabular}{l}
0 \\
\multirow{2}{0}{} \\
0
\end{tabular} \\
\hline 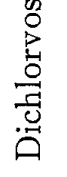 & $\begin{array}{ll}\overrightarrow{1} & 0 \\
0 & 10 \\
0 & 0 \\
0 & 0\end{array}$ & 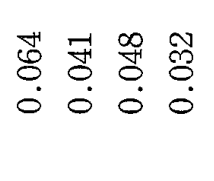 & 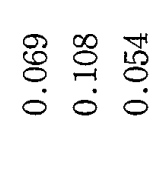 & $\begin{array}{l}\mathscr{\infty} \\
0 \\
0\end{array}$ & 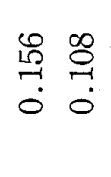 & 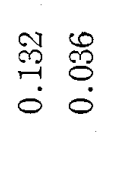 & $\begin{array}{lllll}\dddot{T} & 0 & 0 & 0 & \pi \\
0 & 0 & 0 & 0 & 0 \\
0 & 0 & 0 & 0 & 0\end{array}$ & $\begin{array}{l}\stackrel{0}{\circ} \\
\dot{0} \\
0\end{array}$ \\
\hline 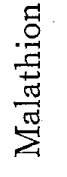 & 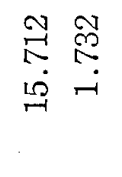 & 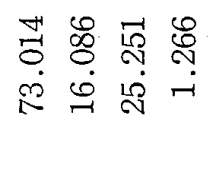 & 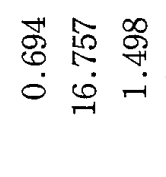 & $\underset{ت}{\stackrel{\vec{H}}{ت}}$ & 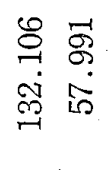 & $\begin{array}{ll}\stackrel{ }{H} & 2 \\
00 & 0 \\
0 & 0\end{array}$ & 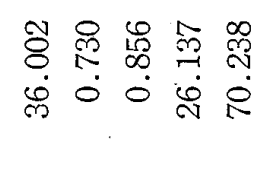 & 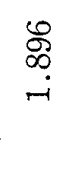 \\
\hline 鿖 & 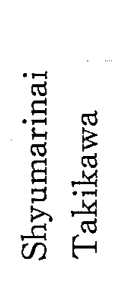 & 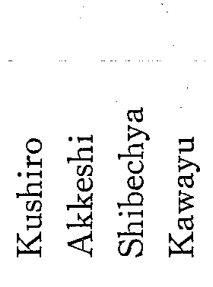 & 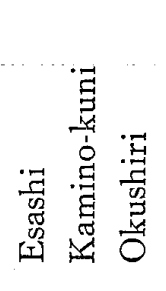 & 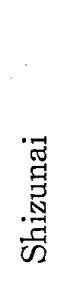 & 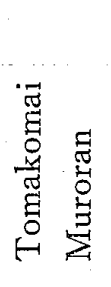 & 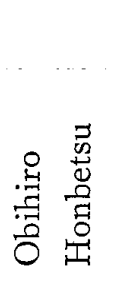 & 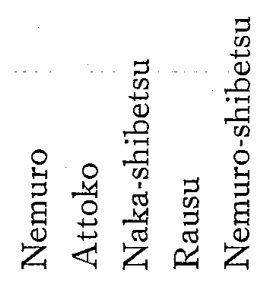 & 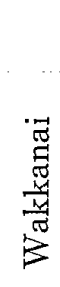 \\
\hline 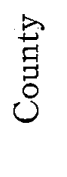 & 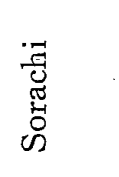 & 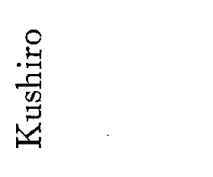 & 䓧 & 焉 & $\stackrel{\vec{G}}{\vec{G}}$ & 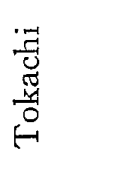 & 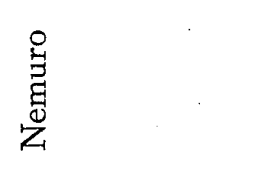 & 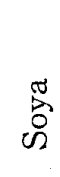 \\
\hline
\end{tabular}


Table 2. LD values for 8 insecticides of the adult female house flies in Honshu $(\mu \mathrm{g} / \mathrm{fly})$

\begin{tabular}{l|r|c|c|c|c|c|c|c}
\hline \multicolumn{1}{c|}{ Colony } & Malathion & Dichlorvos & Fenitrothion & Diazinon & Bromophos & Lindane & Allethrin & Pyrethrins \\
\hline Takatsuki & 0.454 & 0.076 & 0.088 & 0.293 & 0.161 & 4.547 & 0.481 & 0.387 \\
Kochi (Toichi) & 1.167 & 0.052 & 0.241 & 0.575 & 0.325 & 7.279 & 0.859 & 0.728 \\
Hachimantai & 51.589 & 0.068 & 0.243 & 0.359 & 0.123 & 3.432 & 0.839 & 0.297 \\
Aomori & 4.926 & 0.085 & 0.299 & 0.502 & 0.238 & 3.292 & 1.126 & 0.767 \\
Morioka & 58.025 & 0.083 & 0.189 & 0.233 & 0.124 & 3.627 & 0.751 & 0.321 \\
& & & & & & & &
\end{tabular}

workers were nearly locationg around $0.5 \mu \mathrm{g}$ per female fly, for example, $0.5016 \mu \mathrm{g}$ in the RP strain (Yasutomi, 1960, $61 \mathrm{~b}$ ), $0.59 \mu \mathrm{g}$ and $0.589 \mu \mathrm{g}$ in the Denken and Hokota strains (Suzuki et al. 1961; Yasutomi, 1961 b). Recently, Yasutomi (1968) reported that the high resistance in houseflies to malathion was found at Yumenoshima Island, the 15th dumping island in Tokyo Bay and Matsudo dumping site in Chiba Prefecture, the LD50 values being $18.51,25.26$ and $10.35 \mu \mathrm{g}$ respectively. The high resistance recognized on the flies in Hokkaido is quite notable because this insecticide has been used seldom in Hokkaido. In the flies collected Sapporo, Kitami, Rusutsu, Ishikari-tobetsu, Memanbetsu and Onuma, the LD50 values for malathion ranged between 0.818 and 213.388 $\mu \mathrm{g}$, being 1.8-470 times of that of Takatsuki strain.

Comparison of the resistance to allethrin: The LD50 values of the flies from Memanbetsu $(1.104 \mu \mathrm{g})$, Nayoro $(1.186 \mu \mathrm{g})$ and Onuma $(1.308 \mu \mathrm{g})$ were higher than that of the Takatsuki strain $(0.481 \mu \mathrm{g})$. These values were not so higher than $1.180 \mu \mathrm{g}$ reported by Ogami (1970), and $0.712 \mu \mathrm{g}$ by Nakanishi (1970).

Comparison of the resistance to pyrethrins: The LD50 values of the flies from Rausu $(0.643 \mu \mathrm{g})$, Obihiro (0.672 $\mu \mathrm{g})$, Monbetsu (0.774 $\mu \mathrm{g})$, Naka-yubetsu $(0.670 \mu \mathrm{g})$, Rubeshibe $(0.640$ $\mu \mathrm{g})$, Tomakomai $(0.485 \mu \mathrm{g})$, Iwanai $(0.939 \mu \mathrm{g})$, Nayoro $(0.878 \mu \mathrm{g})$ and Furen $(0.591 \mu \mathrm{g})$ were higher than the Takatsuki strain $(0.387 \mu \mathrm{g})$.

Comparison of the resistance to dichlorvos: The Takatsuki strain $(0.076 \mu \mathrm{g})$ seemed to be more tolerant to dichlorvos if it was compared with the Hokota strain $(0.042 \mu \mathrm{g})$ and Matsudo strain $(0.023 \mu \mathrm{g})$ reported by
Yasutomi (1968) and the Denken strain (0.031 $\mu \mathrm{g})$ tested by Suzuki (1968). The flies collected by the authors from Obihiro $(0.132 \mu \mathrm{g})$, Rusutsu $(0.156 \mu \mathrm{g})$ and Tomakomai $(0.156 \mu \mathrm{g})$ were much resistant to dichlorvos than the Takatsuki strain.

Comparison of the resistance to diazinon: The LD50 values of the flies from Nemuro $(0.659 \mu \mathrm{g})$, Okushiri $(0.719 \mu \mathrm{g})$, Kamino-kuni $(0.751 \mu \mathrm{g})$, Saroma $(0.623 \mu \mathrm{g})$, Memanbetsu (I) $(0.669 \mu \mathrm{g})$, Memanbetsu (II) $(0.703 \mu \mathrm{g})$, Shikotsuko $(0.714 \mu \mathrm{g})$ and Nakayama-toge $(0.828$ $\mu \mathrm{g})$ were higher than the value of the Takatsuki strain $(0.293 \mu \mathrm{g})$.

Comparison of the resistance to fenitrothion : Every colony of housefly collected in Hokkaido except for Ishikari-tobetsu colony, tended to be slightly resistant to fenitrothion as compared with the Takatsuki strain $(0.088 \mu \mathrm{g})$.

Bromophos: The susceptibilities of flies in Hokkaido to this insecticide were similar to those observed in the test with fenitrothion. Bromophos seems to be a hopeful insecticide, because it has very. low toxicity in mice, the LD50 value being $5.0 \mathrm{~g} / \mathrm{kg}$.

\section{CONCLUSION}

Houseflies were collected from 44 places in Hokkaido and 5 places in Honshu, and their resistance levels to lindane, malathion, diazinon, dichlorvos, bromophos, fenitrothion, allethrin and pyrethrins were evaluated. It was found that many housefly colonies in Hokkaido were much resistant to these insecticides than the Takatsuki strain. All samples of flies from Hokkaido were resistant to malathion, especially notably high LD50 values were obtained in the flies from Sapporo $(213.388 \mu \mathrm{g})$, Tomakomai $(132.106 \mu \mathrm{g})$ and 
Kitami $(112.437 \mu \mathrm{g})$. These LD values were far much higher than the LD50 value of $25.26 \mu \mathrm{g}$ obtained in the flies from the 15th dumping island (Tokyo). The flies in Hokkaido, however, were found to be still susceptible to both of the pyrethroid insecticides and dichlorvos.

\section{ACKNOWLEDGEMENTS}

The authors wish to express their hearty thanks to Dr. K. Iyatomi and Dr. T. Saito of Nagoya University and Dr. K. Yasutomi of the National Institute of Health for valuable suggestions and advices.

\section{REFERENCES}

1) Nagasawa, S. (1962): Lindane-resistance in the so-called "Takatsuki" strain of the common house fly, Musca domestica vicina. (Problems on the Breeding of Insects for Biological Assay of Insecticides. XXX) BOTYU-KAGAKU, 27 : 108-113. -2) Nakanishi, M. et al. (1970) : Insecticidal activity of a new pyrethroid: Kikuthrin. Studies on insecticide III. BOTYU-KAGAKU, 35 : 91-96. -3) Ogami, H. et al. (1970) : Insecticidal activity of a new synthetic chrysanthemic ester. 5-Propargylfurfury Chrysanthemate (Prothrin). BOTYU-KAGAKU, 35 : 45-55. -4) Suzuki, T. et al. (1962) : Comparative effect of several organophosphorus insecticides to housefly. Jap. J. Sanit. Zool., 13:44-56. -5) Yasutomi,
K. (1960): Studies on the insect-resistance to insecticides VI. Insecticide resistance in the RP strain of house fly. ibid., $\mathbf{1 1}: 112-114 . \quad-6)$ Yasutomi, K. (1961 a) : Studies on the insecticideresistance in Japanese insects of medical importance with special reference to the human lice and housefly. ibid., 12:36-76. -7) Yasutomi, K. (1961 b) : Development and decrease of resistance of house flies to diazinon. ibid., $12: 124-129$. -8) Yasutomi, K. (1968) : Inhibition of esterases by organophosphates and carbamates in housefly (I). ibid., 19 : 44-51.

\section{摘 要 \\ 北海道に拉けるイエバエ成虫の殺虫 鼡感受性について}

北海道内 44 個所と本州の 5 個所で採集したイエバエ 成虫の殺虫剤感受性をしらべた。笑験に用いた殺虫剤は malathion, dichlorvos, diazinon, fenitrothion, bromophos, lindane, allethrin および pyrethrins の 8 種 類である.実験は局所施用法により $L D_{50}$ 值を求め,相互 の比較を行なつた．とくに興味ぶかい点は北海道ではほ とんど malathion が使用されていないにもかかわらず, 非常に強い抵抗性をしめしたことである。 また, lindane に対してもかなり強い抵抗性をしめすものがあつた。し かし，交差抵抗性はとくに認められなかつた。 字た pyrethroid に対しての抵抗性は発達していなかつた. なお, malathion に強い抵抗性をしめすむのでも, 他の 有機橉殺虫剤で駆除し得るものと考えられる.ことに， bromophos は今後, 興味ぶかい殺虫片亡思われる. 